\title{
Estimation of genetic variability, correlation and path coefficient analysis in local landraces of rice (Oryza sativa L.) for the improvement of salinity tolerance
}

\author{
Md. Rasel ${ }^{1}$, Lutful Hassan ${ }^{1}$, Md. Injamum-Ul-Hoque ${ }^{2}$ and Setu Rani Saha ${ }^{1}$ \\ ${ }^{1}$ Department of Genetics and Plant Breeding, Faculty of Agriculture, Bangladesh Agricultural University, Mymensingh-2202, \\ Bangladesh \\ ${ }^{2}$ Department of Crop Botany, Faculty of Agriculture, Bangladesh Agricultural University, Mymensingh-2202, Bangladesh
}

ARTICLE INFO

Article history:

Received: 25 February 2018

Accepted: 18 April 2018

Keywords:

Genetic variability, Heritability, Genetic advance, Correlation and Path analysis

Correspondence:

Lutful Hassan

(lutfulhassan@yahoo.co.uk)

\begin{abstract}
Twenty eight local rice landraces were assessed for eleven morphological traits for the improvement of salt tolerance ability of rice genotypes. Genotypic variance $\left(\sigma^{2} \mathrm{~g}\right)$, phenotypic variance $\left(\sigma^{2} \mathrm{p}\right)$, phenotypic co-variance (PCV), genotypic co-variance (GCV), heritability, genetic advance, genetic advance as a percentage of mean, correlation coefficient and path coefficient were estimated. For all the traits, PCV was higher than the GCV indicating that they were controlled by non-additive gene action and selection for the improvement of these traits would be promising. Among the traits, survival rate of plant exhibited high estimates of PCV (460.72) and GCV (324.73) indicated wide range of variability for these traits where lowest phenotypic coefficient of variation (PCV) and genotypic coefficient of variation (GCV) where low PCV and GCV were observed for root dry weight $(0.17 \& 0.12)$ followed by shoot dry weight $(0.31 \& 0.16)$ and total number of roots $(0.61 \& 0.34)$ indicating lack of inherent variability and limited scope for improvement through selection for these traits among the genotypes. Highest heritability had observed in all traits except chlorophyll content and root length and maximum value of heritability was noticed for shoot length $(75.96 \%)$. High heritability along with high genetic advance was noticed for survival rate of plant $(31.14 \%$ ) followed by live leaves percentage (11.98) and the lowest genetic advance was found in root dry weight $(0.58)$ and shoot dry weight $(0.58)$. Correlation study revealed that significant negative correlations at both phenotypic and genotypic level exist between standard evaluation score (SES) and survival rate (\%), root length, shoot length, root fresh weight, root dry weight and shoot dry weight at the seedling stage further confirmed the importance of these parameters as useful selection criteria for screening for salt tolerance rice genotypes. Path analysis revealed that the root length (0.487), root dry weight (0.394) and shoot dry weight $(0.047)$ had direct positive effect on standard evaluation score at genotypic level where live leaves (\%) per plant $(0.168)$, total number of roots $(0.006)$, chlorophyll content $(0.243)$ and shoot fresh weight $(0.102)$ had direct positive effect on standard evaluation score at phenotypic level. From the correlation and path analysis it can be concluded that root length, root dry weight and shoot dry weight would be more promising for the improvement of salt tolerance in rice genotypes.
\end{abstract}

\section{Introduction}

Rice (Oryza sativa L.) is a self-pollinated cereal crop belonging to the family Poaceae and subfamily Oryzoide (Hooker, 1894; Chakravarthi and Naravaneni, 2006). It is the staple food for more than half of the global population around the world. (Ramkumar, 2010; Datta and Khush, 2002). Approximately $11 \%$ of the world's arable land is used for rice cultivation annually (Chakravarthi and Naravaneni, 2006). About $90 \%$ of the world's rice is cultivated and consumed in Asia (IRRI, 2013). In Bangladesh, rice is mainly grown in three seasons namely Boro (post-monsoon) from December to April, Aus (pre-monsoon) from April to July and Aman (monsoon) from July to December (Deshapriya et al., 2014). Among these seasons, Aman occupied the highest area coverage $(48.74 \%$ of total rice cropped area) (Anonymous, 2009). However, the average rice yield in Bangladesh was 3.048 tones/ha in 2015-2016 (BBS, 2016), which is much lower compared to those of other
Asian countries such as China, South Korea, Indonesia, Japan and Vietnam. Bangladesh is a deltaic country with total area of $1,47,570 \mathrm{~km}^{2}$. Major portion of this land area is suitable for rice cultivation in our country. However, coastal areas covers more than $30 \%$ of cultivable land of our country and $53 \%$ of the coastal land are affected by varying degree of salinity (Haque, 2006). Growing population of our country is creating more pressure on food and therefore, it has become important to explore the possibilities of increasing the potential use of saline areas for increased production of rice. So, improving salt tolerance capability of rive genotypes will help us to achieve higher rice production for meeting the demands of ever-increasing population.

In order to harness the productivity potential of novel materials, it is important to understand the magnitude and nature of genetic variability and association of various agro-morphological traits with grain yield under normal, sodic as well as saline environments. Genetic 
variability is a prerequisite for initiating appropriate breeding procedures in crop improvement programs. Genetic parameters help to understand the gene action, identification of components of genetic variances and finally facilitate the selection of a desirable breeding method. The genotypic variance and phenotypic variance influences the heritability estimates as well as the environmental factors. The heritability and genetic advance are important selection parameters and more helpful in predicting the genetic gain under effective selection (Bisne et al., 2009). Correlation coefficients indicate the magnitude of association between or among traits. The correlation coefficients provide information about interrelationship among yield and its components, which is very helpful for the development of efficient selection strategy. Moreover, path coefficient analysis partitions the correlation coefficients into its direct and indirect effects, so that the contribution of each character to yield could be estimated for picking up appropriate traits for indirect selection. The nature and extent of genetic variability and association parameters are expected to be influenced by the genetic material under study and the prevailing environmental factors. Therefore, an attempt has been undertaken to study the genetic parameters of rice to develop the selection criteria for the traits related to crop yield salinity stress.

\section{Materials and Methods}

This study was conducted at the growth chamber, Department of Genetics and Plant Breeding, Bangladesh Agricultural University (BAU), Mymensingh-2202, Bangladesh. It was started on $16^{\text {th }}$ July 2016 and continued till $14^{\text {th }}$ June 2017. A total of 28 rice genotypes were used in this experiment (Table 1). Twenty five genotypes were local genotypes (landraces) collected from southern part of Bangladesh and three genotypes were high yielding varieties collected from Bangladesh Institute of Nuclear Agriculture (BINA). The experiment was laid out in RCBD with three replications and three treatments (Control, EC- $7 \mathrm{dsm}^{-1}$ and EC- $12 \mathrm{dsm}^{-1}$ ). Plants were maintained in the growth chamber. Four to five days old seedlings were transferred to hydroponic medium by wrapping the lower part of seedling with sponge and placed into the holes. Salt treatments were imposed by adding $\mathrm{NaCl}$ to observe the performance of the rice seedlings at different salinity levels. During salinization, for adjusting the EC$7 \mathrm{dSm}^{-1}$ and EC-12 $\mathrm{dSm}^{-1}, 2.5 \mathrm{~g}$ and $4.25 \mathrm{~g} \mathrm{NaCl}$ per liter nutrient solution were added, respectively. Afterwards, crude salt was added to water at first and mixed it properly by magnetic stirrer to make saline solution. Afterwards, saline solution was dissolved with nutrient solution to reach the desired salinity level. The salinity level was measured as EC using the EC meter.

Data were recorded for live leaves (\%LL), survival rate of plant (\%SR), total number of roots (TNR), shoot length (SL), root length (RL), chlorophyll content (CC), root fresh weight (RFW), shoot fresh weight (SFW), root dry weight (RDW) and shoot dry weight (SDW). All of the data were recorded in both normal and salinized conditions in the laboratory at 18 days of hydroponic setting after harvesting. Percentages of the live leaves were measured by dividing the number of live leaves by total number of leaves multiplied by hundred. The length of the root was measured from the point of shoot initiation to the root tip and shoot length measured by deducting plant length from root length using centimeter $(\mathrm{cm})$ scale. SPAD meter was used (Chlorophyll Meter, SPAD-502, Minolta, Japan) to measure the relative amount of leaf chlorophyll. SPAD readings were taken from the middle portion of $2^{\text {nd }}$ leaf at seedling stage (day $18^{\text {th }}$ ). Immediately after harvesting, the plants were separated into root and shoot, and the fresh weights of root and shoot were taken carefully by using an electric balance. For the determination of root and shoot dry weight (DW), plant samples were separately enclosed in a brown envelop $(20 \times 10 \mathrm{~cm})$ and oven-dried at $60{ }^{\circ} \mathrm{C}$ for 3 days.

Table 1. List of rice genotypes used for this experiment

\begin{tabular}{clcl}
\hline S1. & Genotypes & Types & $\begin{array}{c}\text { Origin and } \\
\text { Identity }\end{array}$ \\
No. & & & \\
V1 & Goccha & & \\
V2 & Rajashail & & \\
V3 & Ghunsi & & \\
V4 & Bousohagi & & \\
V5 & CR india & & \\
V6 & Kolmilota & & \\
V7 & Khaskini & & \\
V8 & Kathigoccha & & \\
V9 & Inchi & & \\
V10 & Kanchon & & \\
V11 & Lalgotal & & \\
V12 & Hori & & \\
V13 & Durgavog & & \\
V14 & Nonsabokra & & \\
V15 & Kasfulbalam & & \\
V16 & Holdegotal & & \\
V17 & Tejminiket & & \\
V18 & Ruppessor & & \\
V19 & Porodbalam & & \\
V20 & Saiodmota & & \\
V21 & Hogla & & \\
V22 & Khakibiroi & & \\
V23 & Katarongi & & \\
V24 & Kalsi & & \\
V25 & Vusieri & & \\
\hline V26 & BINA dhan-10 & High yielding salt & \\
V27 & BINA dhan-8 & tolerant varieties & BINA \\
V28 & BINA dhan-17 & High yielding & \\
& & varieties & \\
\hline & & & \\
\end{tabular}

\section{Statistical analysis of data}

Correlation co-efficient and path co-efficient were estimated by using BASICA software and genetic parameters such as genotypic and phenotypic variance, heritability, genotypic co-efficient of variation (GCV) and phenotypic co-efficient of variation (PCV), genetic advance were estimated by using the following formula. 
Estimation of genotypic and phenotypic variances

Genotypic and phenotypic variances were estimated according to the formula given by Johnson et al. (1955).

Genotypic variance, $\sigma_{\mathrm{g}}^{2}=\frac{\text { GMS }- \text { EMS }}{\mathrm{r}}$

Where,

GMS $=$ Genotypic mean square

$\mathrm{EMS}=$ Error mean

$\mathrm{r}=$ Number of replication

Phenotypic variance, $\sigma_{\mathrm{p}}^{2}=\sigma_{\mathrm{g}}^{2}+$ EMS

Where,

$\sigma_{\mathrm{g}}^{2}=$ Genotypic variance

EMS $=$ Error mean square

Estimation of genotypic coefficient of variation (GCV) and phenotypic coefficient of variation (PCV)

Genotypic and phenotypic coefficient of variations were estimated according to Burton (1952), and Singh \& Chaudhury (1985).

Genotypic coefficient of variations, $\mathrm{GCV}=\frac{\sqrt{\sigma_{\mathrm{g}}^{2}}}{\overline{\mathrm{X}}} \times 100$

Where,

$\sigma_{\mathrm{g}}^{2}=$ Genotypic variance; and

$\overline{\mathrm{X}}=$ Population mean

Phenotypic coefficient of variations, $\mathrm{PCV}=\frac{\sqrt{\sigma_{\mathrm{p}}^{2}}}{\overline{\mathrm{X}}} \times 100$

Where,

$\sigma_{\mathrm{p}}^{2}=$ Phenotypic variance; and

$\overline{\mathrm{X}}=$ Population mean

\section{Estimation of heritability}

Heritability in broad sense $\left(h^{2} b\right)$ was estimated according to the formula suggested by Johnson et al., (1955) and Hanson et al., (1956).

Heritabili ty, $\mathrm{h}_{\mathrm{b}}^{2}=\frac{\sigma_{\mathrm{g}}^{2}}{\sigma_{\mathrm{p}}^{2}} \times 100$

Where,

$\mathrm{h}^{2} \mathrm{~b}=$ Heritability in broad sense

$\delta^{2} \mathrm{~g}=$ Genotypic variance; and

$\delta^{2} \mathrm{p}=$ Phenotypic variance

\section{Estimation of genetic advance}

Estimation of genetic advance was done following formula given by Johnson et al. (1955) and Allard (1960).

Genetic advance, $\mathrm{GA}=\mathrm{h}_{\mathrm{b}}^{2} \cdot \mathrm{K} \cdot \sigma_{\mathrm{p}}$ Where,

$\mathrm{h}_{\mathrm{b}}^{2}=$ Heritability in broad sense

$\mathrm{K}=$ Selection differential, the value of which is 2.06 at $5 \%$ selection intensity

$\sigma_{\mathrm{p}}=$ Phenotypic standard deviation
Estimation of genetic advance in percentage of mean, GA (\%)

Genetic advance in percent of mean was calculated by the formula of Comstock and Robinson (1952) as follows:

Genetic advance in percentage of mean,

GA $(\%)=\frac{G A}{\bar{X}} \times 100$

Where,

$\mathrm{GA}=$ Genetic advance

$\overline{\mathrm{X}}=$ Population mean

\section{Results and Discussion}

\section{Genetic variability of the traits}

A wide range of variation was found for all the traits among 28 rice genotypes which indicates that there were large genetic differences exist among the genotypes (Table 2). The genetic analysis showed that the phenotypic co-efficient of variation (PCV) was higher than genotypic coefficient of variation (GCV) for all the characters (Table 2) studied indicating the presence of environmental influence to some degrees in the phenotypic expression of the characters. Akanda et al. (1997) also reported similar findings for the screening of rice genotypes for salt tolerance. The difference between genotypic and phenotypic coefficient of variability indicates the environmental influence. The higher values of PCV and GCV further facilitate the possibility of improvement of those genotypes for salt tolerance through the selection of desired characters. Among the traits, survival rate exhibited high estimates of PCV (460.72) and GCV (324.73) followed by live leaves (\%) (115.40 \& 62.47) and shoot length (20.77 \& 15.77) (Table 2) indicated wide range of variability for these traits where lowest phenotypic coefficient of variation (PCV) and genotypic coefficient of variation (GCV) were observed for root dry weight $(0.17 \& 0.12)$ followed by shoot dry weight $(0.31 \& 0.16)$ and total number of roots $(0.61 \& 0.34)$ (Table 2$)$. Very low GCV of root dry weight (0.12) followed by shoot dry weight $(0.16)$ and total number roots $(0.34)$ (Table 2$)$ indicating lack of inherent variability and limited scope for improvement through selection for these traits among the genotypes.

Heritability would be an important parameter in plant breeding to select for the high heritable plant trait. The results from the present study reported that live leaves (\%) $(54.13 \%)$, survival rate $(\%)(70.42 \%)$, total number of roots $(55.54 \%)$, shoot length $(75.96 \%)$, root fresh weight $(67.72 \%)$, root dry weight $(67.46 \%)$, shoot fresh weight $(65.34 \%)$, shoot dry weight $(50.42 \%)$ and standard evaluation score (64.62\%) showed high heritability where chlorophyll content $(49.72 \%)$ and root length (48.72\%) expressed moderate heritability (Table 2). Gana et al. (2013) also found the similar result and reported that high heritability was expressed among twelve morpho-physiological characters of thirty 
nine varieties. High heritability values indicate that the traits under study are less influenced by environment for their phenotypic expression and selection could be made by using these traits to improve rice genotypes for salt tolerance. Therefore, the plant breeder may select a genotype based on phenotypic expression for the desired characters of individual plant through simple selection method. High heritability along with high genetic advance was noticed for survival rate $(70.42 \% \& 31.14)$ (Table 2) suggested that high heritability combined with high genetic advance could be an indication of additive gene action and selection based on these parameters would be more reliable. Hosseini et al. (2012) also found high genetic advance for plant height, root dry weight and shoot length. It indicates that accumulation of more additive genes will be leading to further improvement for their performance. Furthermore, high heritability with moderate or low genetic advance was found in all other traits studied in the present study. It can facilitate the possibility of improvements by intermitting superior genotypes of segregating population developed from combination breeding as reported by Samadia (2005).

High heritability coupled with high genetic advance as percent of mean was observed for shoot length $(75.96 \%$, $47.48 \%)$, survival rate $(70.42 \%, 48.77 \%)$, root dry weight $(67.46 \%, 64.81 \%)$ and standard evaluation score $(64.62 \%, 44.88 \%)$ (Table 2). It's indicates the role of additive gene expression for these traits and would facilitate better scope for improvement of these traits through direct selection.

\section{Correlation among the traits}

Correlation co-efficient among different traits of twenty eight rice genotypes at phenotypic and genotypic level revealed significant and negative relations of standard evaluation score with survival rate (\%), root length, shoot length, root fresh weight, root dry weight and shoot dry weight for all the genotypes (Table 3) which implied that salt tolerant genotypes (having lower salt tolerance score) exhibited higher survival rate (\%), root length, shoot length, root fresh weight, root dry weight, and shoot dry weight. Peng et al. (1999) also reported that increasing plant height would allow the greater biomass production. The highly significant correlations between SES and survival rate (\%), root length, shoot length, root fresh weight, root dry weight and shoot dry weight at the seedling indicating their importance as useful selection criteria for improvement of salt tolerance genotypes. Afterwards, negative and nonsignificant co-relation was found for live leaves (\%), total number of roots and chlorophyll content (Table 3) which referred to a complex linked of relation among the pair of combinations. It was also observed that the genotypic correlation coefficients were higher than their respective phenotypic co-relation coefficient in most cases, indicating strong inherent association between the characters studied and suppressive effect of the environment on the phenotypic expression of these characters reducing phenotypic correlation values.
However, in some cases, the phenotypic correlation coefficients were higher than their corresponding genotypic correlation coefficients suggesting both environmental and genotypic correlation has same effect and finally maximize their expression at phenotypic level. Bai et al. (1992) also reported that the genotypic correlations were greater than the phenotypic values in medium duration rice varieties.

\section{Path analysis of the traits}

An estimate of simple correlation would not provide the true contribution of the characters towards the yield and this simple correlation could be partitioned into direct and indirect effects through path coefficient analysis. Path analysis allows separating the direct effect and their indirect effects through other attributes by apportioning the correlations for better interpretation of cause and effect. The path coefficient analysis showed that root length (0.487), root dry weight (0.394) and shoot dry weight $(0.047)$ had direct positive effect on standard evaluation score at genotypic level (Table 4) where live leaves (\%) (0.168), total number of roots (0.006), chlorophyll content $(0.243)$ and shoot fresh weight $(0.102)$ had direct positive effect on standard evaluation score at phenotypic level (Table 5) indicating their importance in determining complex characters. A similar finding has also been reported by Osman et al. (2012). Chlorophyll content $(-0.065)$ had maximum direct negative effect on standard evaluation score followed by total number of roots $(-0.101)$, live leaves $(\%)(-0.112)$, root fresh weight $(-0.267)$, shoot length $(-0.417)$, shoot fresh weight $(-0.538)$ and survival rate $(-0.675)$ at genotypic level (Table 4) and root fresh weight $(-0.081)$ had maximum direct negative effect on standard evaluation score at phenotypic level followed by shoot length $(-0.106)$, survival rate $(-0.113)$, shoot dry weight $(-0.153)$, root length $(-0.172)$ and root dry weight $(-0.594)$ (Table 5).

When correlation coefficient is negative and the direct effect is highly positive, a restricted simultaneous selection model is to be followed, i.e. restrictions are to be imposed to nullify the undesirable effect in order to make use of the direct effect (Sing et al., 1997; Rashid et al., 2010). The residual effect determines how best the causal factors account for the variability of the dependent factor such as standard evaluation score. The residual effect was 0.4731 and 0.931 at phenotypic and genotypic level (Table $4 \& 5$ ) respectively in case of the present study. Residual effect at phenotypic level 0.4731 indicated that the characters which are selected in this study contributed $53 \%$ of variability on standard evaluation score. From the above discussions it can be concluded that that root length, root dry weight and shoot dry weight had significant genotypic correlation with standard evaluation score as well as employed positive direct effect on standard evaluation score suggesting the selection for these traits would be helpful for the screening and improvement of salt tolerance ability of plant. 
Table 2. Estimation of genetic parameters for morphological characters of twenty eight rice genotypes

\begin{tabular}{llllllll}
\hline Characters & $\begin{array}{l}\text { Phenotypic } \\
\text { variance }\left(\boldsymbol{\delta}^{\mathbf{2}} \mathbf{p}\right)\end{array}$ & $\begin{array}{l}\text { Genotypic } \\
\text { variance }\left(\boldsymbol{\delta}^{\mathbf{2}} \mathbf{g}\right)\end{array}$ & $\begin{array}{l}\text { PCV } \\
\mathbf{( \% )}\end{array}$ & $\begin{array}{l}\text { GCV } \\
\mathbf{( \% )}\end{array}$ & $\begin{array}{l}\text { Heritability } \\
\mathbf{( \% )}\end{array}$ & GA & GA (\%) \\
\hline LL (\%) & 115.40 & 62.47 & 26.37 & 19.40 & 54.13 & 11.98 & 29.40 \\
SR (\%) & 460.72 & 324.43 & 33.62 & 28.21 & 70.42 & 31.14 & 48.77 \\
TNR & 0.61 & 0.34 & 18.16 & 13.54 & 55.54 & 0.89 & 20.78 \\
RL (cm) & 1.32 & 0.64 & 14.93 & 10.42 & 48.72 & 1.15 & 14.98 \\
SL(cm) & 20.77 & 15.77 & 30.34 & 26.44 & 75.96 & 7.13 & 47.48 \\
CC & 12.01 & 5.97 & 26.42 & 18.63 & 49.72 & 3.55 & 27.06 \\
RFW (mg) & 2.13 & 1.44 & 19.96 & 16.42 & 67.72 & 2.04 & 27.84 \\
RDW (mg) & 0.17 & 0.12 & 46.64 & 38.31 & 67.46 & 0.58 & 64.81 \\
SFW (mg) & 2.85 & 1.86 & 18.79 & 15.19 & 65.34 & 2.27 & 25.29 \\
SDW (mg) & 0.31 & 0.16 & 37.84 & 26.87 & 50.42 & 0.58 & 39.31 \\
SES & 2.29 & 1.48 & 33.70 & 27.09 & 64.62 & 2.01 & 44.86 \\
\hline
\end{tabular}

Notes: LL (\%) = live leaves (\%), SR (\%) = Survival Rate, TNR = Total number of roots, RL = Root length $(\mathrm{cm})$, SL $=$ Shoot length $(\mathrm{cm}), \mathbf{C C}=$ Chlorophyll content, RFW = Root fresh weight $(\mathrm{mg}), \mathbf{R D W}=$ Root dry weight $(\mathrm{mg})$, SFW $=$ Shoot fresh weight $(\mathrm{mg}), \mathbf{S D W}=$ Shoot dry weight $(\mathrm{mg})$ and SES= Standard evaluation score.

Table 3. Correlation Coefficients of different morphological traits of 28 rice genotypes at phenotypic and genotypic level

\begin{tabular}{|c|c|c|c|c|c|c|c|c|c|c|c|}
\hline Characters & correlation & $\begin{array}{l}\text { SR } \\
\text { (\%) }\end{array}$ & TNR & $\begin{array}{l}\mathrm{RL} \\
(\mathrm{cm})\end{array}$ & $\begin{array}{l}\text { SL } \\
(\mathbf{c m})\end{array}$ & CC & $\begin{array}{l}\text { RFW } \\
\text { (mg) }\end{array}$ & $\begin{array}{l}\text { RDW } \\
\text { (mg) }\end{array}$ & $\begin{array}{l}\text { SFW } \\
\text { (mg) }\end{array}$ & $\begin{array}{l}\text { SDW } \\
\text { (mg) }\end{array}$ & SES \\
\hline \multirow{2}{*}{ LL (\%) } & $r_{p}$ & 0.212 & 0.233 & 0.330 & $0.427^{*}$ & 0.206 & 0.345 & $0.456^{*}$ & 0.354 & 0.385 & -0.228 \\
\hline & $r_{g}$ & 0.108 & 0.264 & 0.365 & $0.391 *$ & -0.116 & 0.357 & $0.841 * *$ & 0.336 & $0.581 * *$ & -0.107 \\
\hline \multirow{2}{*}{ SR (\%) } & $r_{p}$ & & 0.007 & $0.524 * *$ & $0.457^{*}$ & 0.278 & $0.431^{*}$ & $0.534 * *$ & 0.373 & 0.310 & $-0.510 * *$ \\
\hline & $r_{g}$ & & -0.040 & $0.831 * *$ & $0.459^{*}$ & 0.137 & $0.534 * *$ & $0.857 * *$ & 0.353 & $0.423 *$ & $-0.454^{*}$ \\
\hline \multirow{2}{*}{ TNR } & $r_{p}$ & & & 0.104 & 0.242 & 0.007 & 0.103 & 0.053 & 0.116 & 0.328 & -0.076 \\
\hline & $\mathrm{r}_{\mathrm{g}}$ & & & -0.087 & 0.163 & -0.263 & -0.035 & 0.046 & -0.104 & $0.561 * *$ & -0.087 \\
\hline \multirow{2}{*}{ RL (cm) } & $r_{p}$ & & & & $0.545 * *$ & 0.314 & $0.417 *$ & $0.397 *$ & $0.513 * *$ & $0.573 * *$ & $-0.462 *$ \\
\hline & $r_{g}$ & & & & $0.665 * *$ & 0.207 & $0.609 * *$ & $0.688 * *$ & $0.826 * *$ & $0.856^{* *}$ & $-0.693 * *$ \\
\hline \multirow{2}{*}{ SL (cm) } & $r_{p}$ & & & & & 0.371 & $0.482 * *$ & $0.493 * *$ & $0.395^{*}$ & $0.490 * *$ & $-0.455^{*}$ \\
\hline & $r_{g}$ & & & & & 0.207 & $0.472 *$ & $0.703 * *$ & 0.264 & $0.641 * *$ & $-0.438^{*}$ \\
\hline \multirow{2}{*}{ CC } & $r_{p}$ & & & & & & $0.425^{*}$ & $0.492 * *$ & 0.338 & $0.496 * *$ & -0.215 \\
\hline & $r_{g}$ & & & & & & $0.552 * *$ & $0.908 * *$ & 0.231 & $0.874 * *$ & 0.023 \\
\hline \multirow{2}{*}{ RFW (mg) } & $r_{p}$ & & & & & & & $0.511^{* *}$ & $0.408^{*}$ & $0.480 * *$ & $-0.426^{*}$ \\
\hline & $\mathrm{r}_{\mathrm{g}}$ & & & & & & & $0.660 * *$ & 0.298 & $0.629 * *$ & $-0.471^{*}$ \\
\hline \multirow{2}{*}{ RDW(mg) } & $\mathrm{r}_{\mathrm{p}}$ & & & & & & & & $0.518 * *$ & $0.413^{*}$ & $-0.630 * *$ \\
\hline & $r_{g}$ & & & & & & & & $0.775 * *$ & $0.423 *$ & $-0.874 * *$ \\
\hline \multirow{2}{*}{ SFW (mg) } & $\mathrm{r}_{\mathrm{p}}$ & & & & & & & & & $0.499 * *$ & -0.345 \\
\hline & $r_{g}$ & & & & & & & & & $0.660 * *$ & -0.270 \\
\hline \multirow{2}{*}{ SDW (mg) } & $\mathrm{r}_{\mathrm{p}}$ & & & & & & & & & & $-0.385^{*}$ \\
\hline & $r_{g}$ & & & & & & & & & & $-0.624 * *$ \\
\hline
\end{tabular}

Notes: $r_{p}$ indicates phenotypic correlation and $\mathrm{rg}$ indicates genotypic correlation

LL (\%) = live leaves (\%), SR (\%) = Survival Rate, TNR = Total number of roots, RL = Root length $(\mathrm{cm}), \mathbf{S L}=$ Shoot length $(\mathrm{cm}), \mathbf{C C}=$ Chlorophyll content, RFW = Root fresh weight $(\mathrm{mg}), \mathbf{R D W}=$ Root dry weight $(\mathrm{mg}), \mathbf{S F W}=$ Shoot fresh weight $(\mathrm{mg}), \mathbf{S D W}=$ Shoot dry weight $(\mathrm{mg})$ and $\mathbf{S E S}=$ Standard evaluation score

Table 4. Partitioning of direct and indirect effects of morphological characters of 28 rice genotypes at genotypic level by path coefficient analysis

\begin{tabular}{|c|c|c|c|c|c|c|c|c|c|c|c|}
\hline Characters & $\begin{array}{l}\text { LL } \\
(\%)\end{array}$ & $\begin{array}{c}\text { SR } \\
(\%)\end{array}$ & TNR & $\begin{array}{c}\text { RL } \\
(\mathrm{cm})\end{array}$ & $\begin{array}{c}\text { SL } \\
\text { (cm) }\end{array}$ & CC & $\begin{array}{c}\text { RFW } \\
\text { (mg) }\end{array}$ & $\begin{array}{c}\text { RDW } \\
\text { (mg) }\end{array}$ & $\begin{array}{l}\text { SFW } \\
\text { (mg) }\end{array}$ & $\begin{array}{l}\text { SDW } \\
\text { (mg) }\end{array}$ & SES \\
\hline LL (\%) & -0.112 & -0.073 & -0.027 & 0.178 & -0.163 & 0.008 & -0.095 & 0.331 & -0.181 & 0.027 & -0.107 \\
\hline SR (\%) & -0.012 & -0.675 & 0.004 & 0.405 & -0.191 & -0.009 & -0.143 & 0.337 & -0.190 & 0.020 & $-0.454^{*}$ \\
\hline TNR & -0.029 & 0.027 & -0.101 & -0.042 & -0.068 & 0.017 & 0.009 & 0.018 & 0.056 & 0.026 & -0.087 \\
\hline RL (cm) & -0.041 & -0.561 & 0.009 & 0.487 & -0.277 & -0.013 & -0.163 & 0.271 & -0.445 & 0.040 & $-0.693 * *$ \\
\hline SL (cm) & -0.044 & -0.310 & -0.016 & 0.324 & -0.417 & -0.013 & -0.126 & 0.277 & -0.142 & 0.030 & $-0.438 *$ \\
\hline CC & 0.013 & -0.092 & 0.026 & 0.101 & -0.086 & -0.065 & -0.147 & 0.357 & -0.124 & 0.041 & 0.023 \\
\hline RFW (mg) & -0.039 & -0.360 & 0.004 & 0.297 & -0.197 & -0.036 & -0.267 & 0.260 & -0.160 & 0.029 & $-0.471^{*}$ \\
\hline RDW (mg) & -0.094 & -0.578 & -0.005 & 0.335 & -0.293 & -0.059 & -0.176 & 0.394 & -0.417 & 0.020 & $-0.874 * *$ \\
\hline SFW (mg) & -0.038 & -0.238 & 0.010 & 0.403 & -0.110 & -0.015 & -0.080 & 0.305 & -0.538 & 0.031 & -0.270 \\
\hline SEW (mg) & -0.065 & -0.286 & -0.057 & 0.417 & -0.267 & -0.057 & -0.168 & 0.166 & -0.355 & 0.047 & $-0.624 * *$ \\
\hline
\end{tabular}

Notes: LL (\%) = live leaves (\%), SR (\%) = Survival Rate, TNR = Total number of roots, RL = Root length $(\mathrm{cm})$, SL $=$ Shoot length $(\mathrm{cm}), \mathbf{C C}=$ Chlorophyll content, RFW $=$ Root fresh weight $(\mathrm{mg}), \mathbf{R D W}=$ Root dry weight $(\mathrm{mg}), \mathbf{S F W}=$ Shoot fresh weight $(\mathrm{mg})$, SDW $=$ Shoot dry weight $(\mathrm{mg})$ and SES $=$ Standard evaluation score. 
Table 5. Partitioning of direct and indirect effects of morphological characters of 28 rice genotypes at phenotypic level by path coefficient analysis

\begin{tabular}{|c|c|c|c|c|c|c|c|c|c|c|c|}
\hline Characters & $\begin{array}{l}\text { LL } \\
\text { (\%) }\end{array}$ & $\begin{array}{l}\text { SR } \\
\text { (\%) }\end{array}$ & TNR & $\begin{array}{l}\mathrm{RL} \\
\text { (cm) }\end{array}$ & $\begin{array}{l}\text { SL } \\
(\mathbf{c m})\end{array}$ & CC & $\begin{array}{l}\text { RFW } \\
\text { (mg) }\end{array}$ & $\begin{array}{c}\text { RDW } \\
\text { (mg) }\end{array}$ & $\begin{array}{l}\text { SFW } \\
\text { (mg) }\end{array}$ & $\begin{array}{l}\text { SDW } \\
\text { (mg) }\end{array}$ & SES \\
\hline LL(\%) & 0.168 & -0.024 & 0.0014 & -0.057 & -0.045 & 0.050 & -0.028 & -0.271 & 0.036 & -0.059 & -0.228 \\
\hline SR (\%) & 0.036 & -0.113 & 0.00004 & -0.090 & -0.049 & 0.068 & -0.035 & -0.317 & 0.038 & -0.048 & $-0.510 * *$ \\
\hline TNR & 0.039 & -0.0008 & 0.006 & -0.018 & -0.026 & 0.002 & -0.008 & -0.031 & 0.012 & -0.050 & -0.076 \\
\hline RL (cm) & 0.056 & -0.059 & 0.0006 & -0.172 & -0.058 & 0.076 & -0.034 & -0.236 & 0.052 & -0.088 & $-0.462 *$ \\
\hline $\mathrm{SL}(\mathrm{cm})$ & 0.072 & -0.052 & 0.001 & -0.094 & -0.106 & 0.090 & -0.039 & -0.293 & 0.040 & -0.075 & $-0.455^{*}$ \\
\hline CC & 0.035 & -0.031 & 0.00004 & -0.054 & -0.039 & 0.243 & -0.034 & -0.292 & 0.035 & -0.076 & -0.215 \\
\hline RFW (mg) & 0.058 & -0.049 & 0.0006 & -0.072 & -0.051 & 0.103 & -0.081 & -0.303 & 0.042 & -0.074 & $-0.426^{*}$ \\
\hline RDW (mg) & 0.077 & -0.060 & 0.0004 & -0.068 & -0.052 & 0.120 & -0.041 & -0.594 & 0.053 & -0.063 & $-0.630 * *$ \\
\hline SFW (mg) & 0.060 & -0.042 & 0.0007 & -0.088 & -0.042 & 0.082 & -0.033 & -0.308 & 0.102 & -0.077 & -0.345 \\
\hline SEW (mg) & 0.065 & -0.035 & 0.002 & -0.099 & -0.052 & 0.121 & -0.039 & -0.245 & 0.051 & -0.153 & $-0.385^{*}$ \\
\hline
\end{tabular}

Notes: $\quad$ LL (\%) = live leaves (\%), SR (\%) = Survival Rate, TNR = Total number of roots, RL = Root length $(\mathrm{cm})$, SL $=$ Shoot length $(\mathrm{cm}), \mathbf{C C}=$ Chlorophyll content, RFW $=$ Root fresh weight $(\mathrm{mg}), \mathbf{R D W}=$ Root dry weight $(\mathrm{mg}), \mathbf{S F W}=\mathrm{Shoot}$ fresh weight $(\mathrm{mg})$, SDW $=$ Shoot dry weight $(\mathrm{mg})$ and SES $=$ Standard evaluation score .

\section{Conclusion}

Genetic variability parameters revealed that live leaves (\%), survival rate (\%) and shoot length could be the important parameters for the improvement of alt tolerance genotypes. The results from the correlation and path coefficient analysis indicated that root length, root dry weight and shoot dry weight are the major characters based on which selection would be more reliable for improvement of salt tolerance among the genotypes as this characters not only showed negative and significant association with standard evaluation score but also had high positive direct effect at genotypic level. Therefore, these characters would be reliable criteria for identifying salt tolerant rice genotypes.

\section{References}

Akanda, M.A.L., Alam, M.S. and Uddin, M.M. 1997. Genetic variability, correlation and path analysis in maize (Zea mays L) inbreds. Bangladesh J. Plant Breeding and Gen., 10: $57-61$.

Allard, R.W. 1960. Principles of Plant Breeding. John Wiley and Sons. Inc., New York.

Anonymous. 2009. Statistical Pocket Book of Bangladesh (Bangladesh Burea of Statistics), Ministry of Planning, Government of the People Republic of Bangladesh, pp.175.

Bai, N.R., Devika, R., Regina, A. and Joseph, C.A. 1992. Correlation of yield and yield components in medium duration rice cultivars. Environment and Ecology., 10: 469-470.

BBS. 2016. The Year Book of Agricultural Statistics of Bangladesh. Bangladesh Bureau of statistics. Statistics Div. Ministry. Plan, Govt. Peoples Rep. Bangladesh Dhaka. pp.144.

Bisne, R., Sarwgi, A.K. and Verulka, S.B. 2009. Study of heritability, genetic advance and variability for yield contributing characters in rice. Bangladesh J. Agril. Res., 34(2): 175179.

Burton, G.W. 1952. Quantitative inheritance in Grasses. Proceeding $6^{\text {th }}$ International Grassland Congress. 1: 277-283.

Chakravarthi, B.K. and Naravaneni, R. 2006. SSR marker based DNA fingerprinting and diversity study in rice (Oryza sativa L). African J. Biotech., 5(9): 684-688.

Comstock, R.E. and Robinson, H.F. 1952. Genetic parameters, their estimate and significance. Proceeding 6th International Grassland Congress. 1: 284-291.

Datta, S.K. and Khush, G.S. 2002. Improving rice to meet food and nutritional needs: Biotechnological approaches. J. crop Production. 6(1-2): 229-247.
Deshapriya, N.L., Mahboob, M.G., Hasan, A.K., Hazarika. M. and Samarakoon, L. 2014. Rice production forecasting from Modis Ndvi data in Sylhet region of Bangladesh.

Doehlert, D.C., McMullen, M.S. and Hammond, J.J. 2001. Genotypic and Environmental Effects on Grain Yield and Quality of Oat Grown in North Dakota. Crop Sci., 4: 1066-1072.

Gana, A.S., Shaba, S.Z. and Tsado, E.K. 2013. Principle component analysis of morphological traits in thirty-nine accessions of rice (Oryza sativa L.) grown in a rainfed lowland ecology of Nigeria. J. Plant Breeding and Crop Sci., 5:120-126.

Haque, S.A. 2006: Salinity problems and crop production in coastal regions of Bangladesh. Pak. J. Bot., 38(5): 1359-1365

Hooker, J.D. 1894. The flora of British India. Volume 6, Orchidaceae to Cyperaceae. Reeve.

Hosseini, S.J., Sarvestani, Z.T., Pirdashti, H., Afkhami, A. and Hazrati, S. 2012. Estimationof heritability and genetic advance for screening some rice genotypes at salt stressconditions. Intl. J. Agron. and Plant Production. 3(11): 475-482.

IRRI (International Rice Research Institute). 2013: IRRI World rice Statistics (WRS). online at. http://ricestat.irri.org:8080/ wrsv3/ entrypoint.htm

Johnson, H.W., Robinson, H.F. and Comstock, R.E. 1955. Estimates of genetic and environmental variability in Soybean. Agron.J.,47: 314-318.

Mishra, P.K., Ram, R.B. and Kumar, N. 2015. Genetic variability, heritability and genetic advance in strawberry (Fragaria* ananassa Duch.). Turkish J. Agril. and for. 39: 451-458

Osman, K.A., Mustafa, A.M., Ali, F., Yonglain, Z.and Fazhan, Q. 2012. Genetic variability for yield and related attributes of upland rice genotypes in semi-arid zone (Sudan). African $J$. Agril. Res., 7(33): 4613-4619.

Peng, S., Cassman, K.G., Virmani, S.S., Sheehy, J. and Khush, G.S. 1999. Yield potential trends of tropical rice since the release of IR8 and the challenge of increasing rice yield potential. Crop Sci., 39: 1552-1559.

Ramkumar, G. 2010. Identifying novel alleles of rice blast resistance genes Pikh and Pita through allele mining. International Rice Research Notes. 117: 4185.

Rashid, M.H., Parveen, S. and Bhuiyan, M.S.R. 2010. Genetic variability, correlation and path coefficient analysis in nineteen Brassica rapa germplasm. J. Sher-e-Bangla Agril. Univ., 4(1): 84-89.

Samadia, D.K. 2005. Genetic variability studies in Lasora (Cordiamyxa Roxb.) Indian J. Plant Gen. Res., 18(3): 236240 .

Singh, R.K. and Kakar, S.N. 1977. Control on individual trait means during index selection. Proc. Third Congr. SABRAO (Canberra). 3: 22-25.

Singh, RK. and Chaudhary, B.D. 1985. Biometrical methods of quantitative genetic analysis. Haryana J. Hort. Sci., 12: 151-156. 